\title{
Pendidikan Akhlak Remaja Dalam Keluarga di Desa Mekarwangi Kecamatan Cisauk, Tangerang
}

\author{
Wiwi Cahya Ningsih ${ }^{1}$, Sinta Bela ${ }^{2}$ Ika $^{3}$ \\ ${ }^{1}$ STAI Fatahillah Serpong -Kp. Kandang RT.04/02 Ds. Mekarwangi, Kec. Cisauk, \\ Tangerang. Email: ningsihwiwicahya@gmail.com \\ ${ }_{2}^{2}$ STAI Fatahillah Serpong - Kp. Rancamalang RT.01/02 Ds. Kadusirung, Kec. \\ Pagedangan, Tangerang. E-mail: belasinta786@gmail.com \\ ${ }^{3}$ STAI Fatahillah Serpong -Jl. Lingkar Selatan Kel. Keranggan Kec. Setu Kota \\ Tangerang Selatan. E-mail: ikaclar@gmail.com
}

\begin{abstract}
The position of morals in human life occupies a very important place, because whether an individual or a society is bad or bad depends on how good they are. Moral education in the family is carried out with examples and examples from parents. The behavior and manners of people in the social relationship between mother and father, the treatment of parents towards their children, and the treatment of parents towards other people in the family and community circles will be role models for children. So the child's moral education begins with the education provided by both parents, because the child will imitate the behavior of his parents. If the parents exemplify good behavior, then the child will be good, but on the contrary, if the parents do not reflect good morals, how will they provide good moral education to their children. This study aims to describe how the moral education of adolescents in the family in Kandang Village, Mekarwangi Village RT 04 RW 02 Cisauk Tangerang. Through a phenomenological approach with this qualitative type, it tries to examine more deeply the application of adolescent moral education in families in Mekarwangi village. Research results The results showed that parents in Mekarwangi village have been carried out well, it can be seen from the role of parents as the main mentors who have to teach about morals, so that teenagers will get used to good morals, habituation to adolescents, provide examples. firstly to adolescents also advise children to continue to behave in a moral way. The conclusion is that the moral education of adolescents in the family in Mekarwangi Village RT 04/02 has been carried out well, this can be seen from the parents who have applied morals towards the family, especially for their children. And parents provide good teaching and examples to their children.
\end{abstract}

Keywords: Education, morals, youth, parents

Abstrak: Kedudukan akhlak dalam kehidupan manusia menempati tempat yang sangat penting, sebab baik buruknya suatu individu atau masyarakat tergantung kepada bagaimana akhlaknya. Pendidikan akhlak di dalam keluarga dilaksanakan dengan contoh dan teladan dari orang tua. Perilaku dan sopan santun orang dalam hubungan pergaulan antara ibu dan bapak, perlakuan orang tua terhadap anakanak mereka, dan perlakuan orang tua terhadap orang lain di dalam lingkungan keluarga dan lingkungan masyarakat, akan menjadi teladan bagi anak-anak. Jadi pendidikan akhlak anak itu berawal dari pendidikan yang diberikan oleh kedua orang tua nya, sebab anak akan mencotoh perilaku orang tuanya. Apabila orang tuanya mencontohkan yang baik, maka anak tersebut akan baik, namun sebaliknya apabila dari orang tua saja tidak mecerminkan akhlak yang baik bagaimana mereka akan memberikan pendidikan akhlak yang baik pada anaknya. Penelitian ini betujuan untuk mendeskripsikan mengetahui bagaimana pendidikan akhlak remaja dalam keluarga di Kampung Kandang Desa Mekarwangi RT 04 RW 02 Cisauk Tangerang. Melalui pendekatan fenomenologis dengan jenis kualitatif ini mencoba mengkaji lebih mendalam tentang penerapan pendidikan akhlak remaja dalam keluarga di desa Mekarwangi. Hasil penelitian Hasil penelitian menunjukan bahwa 
orangtua di desa Mekarwangi ini telah terlaksanakan dengan baik, dapat dilihat dari peran Orangtua sebagai pembimbing utama yang harus memberikan pengajaran tentang akhlakul karrimah, sehingga dengan begitu para remaja akan terbiasa berakhlak baik, melakukan pembiasaan kepada anak remaja, memberikan contoh terlebih dahulu kepada anak remaja juga menasehati anak untuk terus berperilaku yang berakhlakul karrimah. Kesimpulan bahwa pendidikan akhlak remaja dalam keluarga di Desa Mekarwangi RT 04/02 sudah dilaksanakan dengan baik, hal ini terlihat dari orang tua yang sudah menerapkan akhlak terhdap keluarga terutama untuk anak-anak nya. Dan orang tua memberikan pengajaran dan contoh yang baik kepada anak mereka.

Kata kunci: Pendidikan, akhlak, remaja, orang tua 


\section{PENDAHULUAN}

Pendidikan adalah usaha membina dan mengembangkan kepribadian manusia baik dibagian rohani atau di bagian jasmani. Ada juga beberapa orang ahli mengartikan pendidikan itu adalah suatu proses pengubahan sikap dan tingkah laku seseorang atau sekelompok orang dalam mendewasakan melalui pengajaran dan latihan. Pendidikan adalah usaha secara sengaja dari orang dewasa untuk dengan pengaruhnya meningkatkan si anak ke kedewasaan yang selalu diartikan mampu menimbulkan tanggung jawab moril dan segala perbuatannya, orang dewasa itu adalah orang tua si anak atau orang tua yang atas dasar tugas kedudukannya mempunyai kewajiban untuk mendidik misalnya guru sekolah, pendeta, atau kiyai dalam lingkungan keagamaan, kepala-kepala asrama dan sebagainya. (Muhibbin Syah: 2013)

Menurut Undang-undang RI Nomor 20 Tahun 2003, tentang Sistem Pendidikan Nasional dalam bab I pasal I, disebutkan bahwa "Pendidikan adalah usaha sadar dan terencana untuk mewujudkan suasana belajar dan proses pembelajaran agar peserta didik secara aktif mengembangkan potensi dirinya untuk memiliki kekuatan spiritual keagamaan, pengendalian diri, kepribadian, kecerdasan, akhlak mulia, serta ketrampilan yang diperlukan dirinya, masyarakat, bangsa dan negara.( dalam Munawar Ni'am,1992). Dengan demikian tugas pendidikan bukan sekedar meningkatkan kecerdasan intelektual, tetapi juga mengembangkan seluruh aspek kepribadian peserta didik. Definisi inilah yang kemudian lebih dikenal dengan istilah tarbiyah, dimana peserta didik bukan sekedar orang yang mampu berfikir, tetapi juga orang yang belum mencapai kedewasaan. Oleh karena itu tidak dapat diidentikkan dengan pengajaran.

Remaja sebagai makhluk sosial yang hidup dan berintegrasi dengan yang lain sesuai dengan tahap perkembangan dan kepribadiannya. Sebagai individu yang berada dalam proses perkembangan kearah kematangan atau kemandirian dan integritas kepribadian. Untuk dapat mencapai kematangan tersebut remaja memerlukan bimbingan dari berbagai pihak karena mereka masih kurang memiliki pemahaman dan wawasan tentang dirinya dan lingkungannya. Masa remaja dikenal sebagai masa yang penuh kesukaran. Bukan saja kesukaran bagi individu yang bersangkutan, tetapi juga bagi orang tuanya, masyarakat, bahkan sering kali bagi polisi. Hal ini disebabkan masa remaja merupakan masa transisi antara masa kanak-kanak dan masa dewasa. Masa transisi ini sering kali menghadapkan individu yang bersangkutan kepada situasi yang membingungkan, disatu pihak ia masih kanak-kanak, tetapi dilain pihak ia sudah harus bertingkah laku seperti orang dewasa.(Sarlito W. Sarwono: 2016).

Kerusakan moral dan buruknya kepribadian tidak hanya terjadi pada orang dewasa, tetapi juga dapat menghinggapi generasi penerus bangsa terutama remaja. Saat ini berbagai penyimpangan-penyimpangan perilaku remaja tidak lagi menjadi hal baru di lingkungan masyarakat, semua itu menandakan tidak tertanamnya nilainilai kepribadian Islam pada diri remaja, hal ini seharusnya menjadi perhatian besar bagi pemerintah, masyarakat dan yang utama yaitu keluarga. Sebagai lingkungan yang paling dekat dengan remaja hendaknya keluarga mengamati dengan jeli setiap perubahan yang terjadi pada diri remaja. Kurangnya bimbingan, perhatian, serta didikan dari keluarga merupakan salah satu penyebab penyimpangan-penyimpangan remaja ditambah lagi dengan lingkungan tempat tinggal yang tidak kondusif bagi perkembangan kepribadian remaja.

Ada keluarga yang hanya memberikan fasilitas di dalam dunia pendidikan, misalnya melanjutkan pendidikannya ke tingkat yang lebih tinggi dengan harapan dari bangku sekolah anak akan belajar segala hal yang dibutuhkan termasuk terhadapperkembangan remaja. Karena kurangnya pengawasan serta bimbingan 
dari keluarga dalam perkembangan remaja serta minimnya pengetahuan tentang ilmu agama, maka remaja yang rasa ingin tahunya sangat besar dapat menjadikannya salah dalam mengartikan sesuatu.

Ditambah lagi dengan perkembangan teknologi yang semakin pesat, informasiinformasi yang berasal dari luar yang begitu mudah diperoleh apabila tanpa pengawasan dari keluarga maka informasi yang diperolehnya akan begitu mudah diserap tanpa disaring terlebih dahulu apakah hal itu layak atau tidak untuk ditiru.

Fasilitas yang diberikan oleh orang tua seperti handphone, laptop sebagai sarana yang menunjang untuk belajar jika tanpa pengawasan dari orang tua atau anggota keluarga lainnya akan mudah disalah gunakan oleh remaja. Remaja adalah generasi penerus yang akan membangun bangsa kearah yang lebih baik yang mempunyai pemikiran jauh ke depan dan kegiatan yang dapat menguntungkan dirinya sendiri,keluarga dan lingkungan sekitar.

Dalam pendidikan akhlak yang paling ditekankan adalah tentang hubungan dengan Allah SWT, karena akhlak kepada Allah SWT, adalah hal terpenting dan merupakan cermin dari setiap orang yang kemudian di internalisasikan ke dalam kehidupan sehari-hari. Selain itu pendidikan akhlak juga menekankan akhlak kepada sesama manusia sebagai makhluk sosial dan hidup dalam masyarakat serta mengajarkan untuk saling menghormati satu dengan yang lainnya.

Penanaman akhlak kepada Allah SWT, bertujuan untuk membina akhlak dalam hal ibadah kepada Allah SWT, dan penanaman akhlak kepada sesama bertujuan untuk membina akhlak remaja agar saling menghormati dan berakhlak baik dengan masyarakat serta lingkungan tempat tinggal.

Akhlak bersal dari bahasa Arab jama' dari bentuk mufradnya Khuluqun yang menurut logat diartikan budi pekerti, perangai, tingkah laku atau tabiat.(Zaharudin, dkk: 2004). Dalam pengertian sehari-hari akhlak umumnya disamakan dengan budi pekerti atau kesusilaan atau juga disebut sopan santun.

Jika dikaitkan dengan kata Islami, maka akan berbentuk akhlak Islami, secara sederhana akhlak Islami diartikan sebagai akhlak yang berdasarkan ajaran Islam atau akhlak yang bersifat Islami. Kata Islam yang berada di belakang kata akhlak dalam menempati posisi sifat. Dengan demikian akhlak Islami adalah perbuatan yang dilakukan dengan mudah, disengaja, mendarah daging dan sumbernya berdasarkan pada ajaran Islam. Akhlak Islam bersifat mengarahkan, membimbing, mendorong, membangun peradaban manusia dan mengobati bagi penyakit sosial dari jiwa dan mental, serta tujuan berakhlak yang baik untuk mendapatkan kebahagiaan di dunia dan akhirat.

Dengan demikian akhlak Islami itu jauh lebih sempurna dibandingkan dengan akhlak lainnya. Jika akhlak lainnya hanya berbicara tentang hubungan dengan manusia, maka akhlak Islami berbicara pula tentang cara berhubungan dengan makhlukmakhluk lainnya seperti hewan, tumbuhan, air, udara dan lain sebagainya. Dengan cara demikian, masing-masing makhluk merasakan fungsi dan eksistensinya di dunia ini.

Dari penjelasan di atas dapat dipahami peneliti bahwa akhlaq itu merupakan suatu tindakan nyata yang dibuat oleh seseorang, yang digunakan untuk mengukur dimana seseorang tersebut dapat berbakti kepada kedua orang tua, baik dengan tutur kata, ataupun do'a, serta dapat menempatkan nilai-nilai ke agamaan dengan baik di lingkungan masyarakat. Seperti yang diperintahkan oleh Allah SWT. untuk berakhlaqul qarimmah terhadap semua orang.

Pendidikan akhlak bertujuan untuk menumbuhkan dan meningkatkan keimanan anak didik yang diwujudkan dalam akhlaknya yang terpuji, melalui pemberian dan pemupukkan pengetahuan, penghayatan, pengalaman peserta didik tentang aqidah dan akhlak Islam, sehingga menjadi manusia muslim yang terus berkembang dan 
meningkatkan kualitas keimanan dan ketakwaan kepada Allah SWT, serta berakhlak mulia dalam kehidupan pribadi, bermasyarakat, berbangsa dan bernegara.

Tujuan utama pendidikan akhlak dalam Islam adalah agar manusia berada dalam kebenaran dan senantiasa berada di jalan yang lurus, jalan yang telah digariskan oleh Allah SWT.(Ali Abdullah Halim Mahmud: 2004). Pendidikan serta bimbingan yang diperoleh dari keluarga merupakan pola bimbingan yang terus berjalan sepanjang masa. Berbagai macam interaksi yang terjadi dalam keluarga baik itu komunikasi, pola tingkah laku merupakan cermin dan yang akan membentuk suatu kepribadian bagi remaja.

Dalam hal ini orang tua memiliki peran yang yang sangat penting terhadap para remaja, seperti yang sudah dijelaskan diatas, orang tua mendidik remaja dengan cara bermacam-macam, jika mendidik remaja hanya melalui nasehat dan memberikan pengarahan terhadap mereka tentang hal-hal yang mereka belum pahami itu tidak cukup, karena remaja sekang sedikit sulit untuk mengerti apa yang dilakukan orang tua nya kepada mereka. Seperti yang sudah peneliti amati dilingkungan sekitar bahwasanya orang tua yang mendidik remaja hanya dengan menasehati belum tentu mereka mendengarkan, dan kadang remaja membantah jika dinasehati orang tua.

Karena tidak semua remaja memiliki sifat akhlakul karimah, maka orang tua harus lebih memperhatikan dan berperan dalam mendidik mereka untuk memiliki akhlakul karimah. Orang tua mendidik remaja menggunakan dengan cara pendekatan. Karena dengan pendekatan sedikit demi sedikit remaja akan dekat dengan orangtua, sehingga akan sedikit lebih mudah untuk mendidik remaja agar menjadi remaja ang berakhlakul karimah.

Pendidikan pertama dan utama bagi anak adalah orangtua, sebab setiap anak belajar berbagai hal dari keluarga khususnya orangtua mengenai kehidupannya kelak. Peranan orangtua sangat berpengaruh dalam mendidik anak-anaknya terutama dalam pendidikan agamanya. Anak merupakan bagian masyarakat yang memikul beban pada masa depan kelak, anak akan tumbuh dewasa dan bersosialisasi dengan lingkungan masyarakat. Sehingga orangtua harus membimbing anak agar dapat menjadi penerus generasi yang memiliki akhlaqul karimah yang lebih baik. (Dindin Jamaluddin: 2013).

Seperti firman Allah SWT, pada surah An-Nisa ayat 9, yang berbunyi seperti berikut:

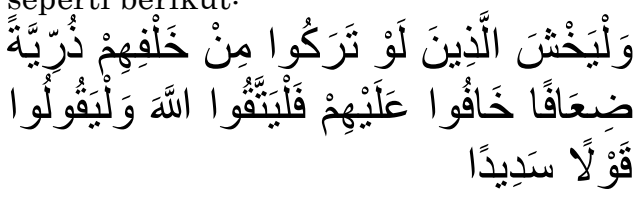

dan hendaklah takut (kepada Alloh) orang-orang yang sekiranya mereka meninggalkan keturunan yang lemah dibelakang mereka yang mereka khawatir terhadap (kesejahteraan) nya. Oleh sebab itu, hendaklah mereka bertakwa kepada Allah.. (Q.S. An-Nisa, 4: 9).

Maksud dari arti di atas ialah mengisyaratkan kepada orangtua agar tidak meninggalkan anaknya dalam keadaan lemah. Maksudnya lemah dalam hal ini yaitu lemah dalam segala aspek kehidupan, seperti lemah mental, psikis, pendidikan, ekonomi terutama lemah iman(Spiritual).

Bahwasanya orangtua merupakan seorang figur yang paling utama di kehidupan anak, karena orangtua adalah lingkungan sosial terkecil di lembaga keluarga atau tempat menuntut ilmu yang awal dan yang baru ia kenal di lingkungan masyarakat. Orangtua yang menentukan bagaimana kualitas seorang anak, dan orangtua merupakan orang yang sangat dekat dengannya, baik secara fisik maupun psikisnya.

Jadi, dalam membina akhlak remaja, orangtua harus dapat melaksanakan kewajiban sebagai pembimbing Orangtua sebagai perawat. Ibu dan ayah mempunyai peranan untuk memelihara kebersihan dan kesehatan anak. Orangtua sebagai pelindung. Pada saat anak mulai merangkak dan berjalan, 
orangtua perlu memberikan perhatian ekstra, untuk menjaga atau melindunginya, karena pada saat itu anak sudah mulai melakukaan pengenalan terhadap lingkungannya. Orangtua sebagai pengasuh. Ketika anak sudah menginjak usia prasekolah orangtua perlu memberikan asuhan atau bimbingan kepada anaknya.

Jika didalam suatu keluarga tidak memberikan perhatian satu sama lain, maka akan berdampak negatif kepada lingkungan keluarga. Seperti banyak yang kita lihat dilingkungan sekitar maupun di media, banyak peristiwaperistiwa yang terjadi ketika suatu keluarga memperlakukan keluarganya dengan biasa-biasa saja. Tidak saling mendukung,tidak saling memberikan perhatian satu sama lain, dan tidak memberikan pemahan yang baik. Sehingga hal seperti ini dapat memicu kepada hal yang negatif di dalam lingkungan keluarga, bahkan terkadang mereka melakukan hal-hal yang kurang baik terhadap orangtua atau keluarga lainnya. Seperti membentak orangtua, berbicara dengan suara yang lantang dan berprilaku kurang sopan.

Hal negatif seperti ini bisamereka dapat dari lingkungan keluarga atau pun di masyarakat. Maka dari itu pendidikan akhlak dalam keluarga sangat penting untuk membentuk kepribadian remaja menjadi lebih baik untuk generasi penerus yang akan membangun bangsa ke arah yang lebih baik. Tidak hanya lingkungankeluarga yang berdampak dengan kepribadian remaja, tetapi juga lingkungan masyarakat sekitar, pergaulan remaja dan aktifitas remaja. Orangtua berperan penting untuk mengawasi kegiatan remaja dimasyarakat, dengan memberikan pengawasan dan mengetahui kegiatan apa saja yang remaja lakukan diluar rumah, karena lingkungan yang kurang baik akanberdampak dengan kepribadian remaja. Tetapi sebaliknya, jika lingkungan sekitar baik dan pergaulanya juga baik serta mendapat pengawasan dari orangtua, maka akan memberikan dampak yang positif kepada remaja.
Disini peneliti akan meneliti objek yang berada di Desa Mekarwangi, khususnya hanya di RT 04 RW 02. Agama yang dianut oleh masyarakat sekitar mayoritas beragama Islam, akan tetapi dalam hal ini yang akan peneliti jadikan objek peneliti yaitu 5 remaja dalam hal ini peneliti membatasi akan usia remaja yang dijadikan objek penelitian, yaitu remaja pertengahan yang berusia 15-18 tahun. Peneliti mengambil objek yang berumur 15-18 karena dilingkungan tempat yang akan diteliti rata-rata adalah remaja berusia seperti yang sudah disebutkan.

Berdasarkan hasil survey yang dilakukan di Desa Mekarwangi RT 04/02 ada beberapa orang tua yang mengajarkan kepada remaja untuk membantu pekerjaan ibunya dan ayah nya dirumah, mengajarkan untuk selalu melakukan ibadah sholat, merawat remaja tersebut agar tetap sehat, memotivasi apabila ia sedih, menasehati bila ia berbuat salah, itu sudah termasuk mendidik remaja, untuk memiliki sifat tolong menolong, empati terhadap orang lain.

Hal ini juga dapat diperkuat oleh adanya hasil wawancara dengan bapak ketua RT 04/02 di Desa Mekarwangi kecamatan Cisauk. Bahwasanya beliau menyatakan orang tua dilingkungan sekitar sudah mendidik para remaja untuk berbuat baik dan sopan santun terhadap orang tua maupun orang lain. Orang tua mendidik remaja dengan cara memberikan contoh teladan, seperti untuk selalu mengerjakan sholat berjamaah di masjid bagi remaja putra dan mengajarkan untuk membaca $\mathrm{Al}-$ Qur'an, taat beribadah, dan disiplin.

Berdasarkan pemaparan masalah di atas, membuat peneliti tertarik untuk melakukan penelitian secara mendalam terkait dengan pendidikan akhlak dalam keluarga. Adapun dalam penelitian ini bertujuan: Untuk mengetahui bagaimana pendidikan akhlak remaja dalam keluarga di Kampung Kandang Desa Mekarwangi RT 04 RW 02 Cisauk Tangerang. 


\section{METODE}

Penelitian ini menggunakan metode penelitian kualitatif dengan pendekatan fenomenologis. Metode penelitian kualitatif mendeskripsikan tentang gejala sosial, aktifitas sosial, dan pemikiran-pemikiran manusia.

Dalam penelitian ini sumber data yang peneliti gunakan yaitu sumber data primer dan sumber data sekunder. Data primer adalah data yang diperoleh langsung dari informan, Penentuan informan dalam penelitian kualitatif menyatakan bahwa dapat dilakukan saat peneliti mulai memasuki lapangan selama penelitian berlangsung yaitu memilih orang tertentu yang dipertimbangkan akan memberikan data yang diperlukan dan selanjutnya berdasarkan data atau informasi lainnya yang diharapkan dapat memberikan data yang lebih lengkap.(Sugiyono: 2017).Sedangkan data sekunder adalah data yang biasanya telah tersusun dalam bentuk dokumen-dokumen yang sudah ada dalam hal ini data digali dengan melihat data-data dokumen seperti koleksi buku, sumber arsip, dokumen pribadi, dokumen resmi, gambar (Foto), yang peneliti temukan pada saat berada di lapangan penelitian.

Adapun yang menjadi informan dalam penelitian ini adalah ketua lingkungan yaitu ketua RT. 04/02 dan 5 orang tua (keluarga) termasuk didalamnya para anak yang berusia remaja. Selain itu peneliti juga di bantu oleh informan pembantu. Informan pembantu ini berfungsi sebagai orang yang membantu peneliti dalam mengumpulkan data seperti merekam, mendokumentasikan, data penelitian.

Teknik pengumpulan data merupakan langkah yang paling utama dalam penelitian, karena tujuan utama dari penelitian adalah mendapatkan data. Tanpa mengetahui teknik pengumpulan data, maka peneliti tidak akan mendapatkan data yang memenuhi standar data yang ditetapkan. (Sugiyono: 2017) Pengumpulan data yang penulis gunakan diantaranya, Observasi (Participan Observation), wawancara dan dokumentasi.
Analisis data dilakukan dengan mengorganisasikan data, menjabarkannya ke dalam unit-unti, melakukan sintesa, menyusun ke dalam pola, memilih mana yang penting dan yang akan dipelajari, dan membuat kesimpulan yang dapat diceritakan kepada orang lain.Adapun analisis data dilakukan peneliti yaitu. Reduksi data (Data Reduction), penyajian data (data display), danverifikasi data(Conclusion drawing)

\section{HASIL}

1. Pendidikan Akhlak Remaja dalam Keluarga di Kampung Kandang Desa Mekarwangi RT. 04 RW.02 Cisauk Tangerang

Pada bagian ini akan dipaparkan temuan hasil selama penelitian berlangsung. Hasil penelitian tersebut diperoleh melalui observasi secara langsung, wawancara dengan berbagai pihak yang terkait dengan pendidikan akhlak remaja dalam keluarga, dan pengumpulan dokumen-dokumen yang ada.

a. Memberi pengajaran akhlakul karrimah kepada remaja.

Peran orangtua di sini memberikan pengajaran dalam arti yang luas, sehingga remaja memperoleh peluang untuk memiliki pengetahuan dan kecakapan seluas dan setinggi mungkin yang dapat dicapainya, apalagi dalam hal akhlakul karrimah. Oleh karena itu, orangtua berperan dalam memberikan pengajaran tentang akhlakul karrimah kepada anaknya yang memasuki remaja pertengahan.

Anak yang memasuki remaja pertengahan merupakan remaja yang mulai aktif dalam setiap hal dan bertambahnya rasa keingintahuannya terhadap berbagai hal, sehingga di sinilah orangtua harus memberikan pengajaran tentang akhlakul karrimah. Orangtua mengajarkan bagaimana bersikap sopan santun terhadap orang lain, saling tolong menolong, mengajarkan kepada anak untuk melakukan ibadah sholat bersama-sama dengan orangtuanya, dan memiliki rasa empati terhadap orang lain. Sehingga 
dengan begitu remaja dapat mempelajari hal-hal positif dari orangtuanya.

Hasil observasi yang Peneliti lakukan terkait dengan pendidikan akhlak remaja dalam keluarga dapat dinilai baik, hal ini dapat dilihat bahwa orangtua sudah memberikan pengajaran tentang akhlakul karrimah kepada remaja. Salah satunya adalah memberi pengajaran tentang sopan santun terhadap orang lain yang lebih tua dari dirinya.

Hal ini sesuai dengan hasil wawancara dengan Ibu Eras, yang menyatakan bahwa: "saya selalu mengajarkan kepada anak saya tentang sopan santun atau berbuat baik, berprilaku baik terhadap orang lain, selalu mendengarkan nasehat yang diberikan kepadanya, dan lain sebagainya."

Ibu Lidya menyatakan bahwa: saya ini orangnya cerewet, jadi saya selalu mengajari anak saya tentang sopan santun secara terus menerus.

Ibu Rodiyah juga menyatakan: "saya sebagai orangtua tentu harus memberikan pengajaran tentang akhlakul karrimah, karena itu merupakan kwajiban orangtua yang harus diberikan."

Bapak Aris juga menyatakan seperti hal di atas bahwa: "didalam kesehariannya saya mengajarkan kepada anak saya untuk selalu bersifat sopan santun.

Bapak Rahmat: iya, saya memberikan pengajaran kepada anak saya karna itu merupakan kewajiban orangtua sebagai pembimbing agar anaknya memiliki akhlakul karrimah."

Hasil wawancara yang Peneliti lakukan terkait dengan pendidikan akhlak remaja dalam keluarga dapat dinilai baik, hal ini dapat dilihat bahwa orangtua sudah memberikan pengajaran tentang akhlakul karrimah kepada remaja menggunakan berbagai macam cara. Salah satunya adalah dengan menggunakan pendekatan, saling berkomunikasi antara orangtua dengan remaja, sehingga dapat menciptakan kepercayaan antara orangtua dengan remaja.
Selanjutnya adalah hasil wawancara dengan para orangtua tentang berbagai cara untuk memberikan pengajaran akhlakul karrimah kepada Remaja.

Ibu Limah: "saya memberikan pengajaran akhlakul karrimah dengan cara menasehatinya, terkadang dengan cara memberikan contoh langsung, seperti yang saya ajarkan ketika berada di rumah membantu mbak-mbaknya membersihkan rumah, sehingga anak saya memahami apa yang saya lakukan kepada orang lain, dan anak saya mampu mengikuti apa yang saya lakukan."

Ibu Erna: "saya mengajarkanya dengan cara memberikan nasehat kepada anak saya, agar anak saya memahami apa yang saya sampaikan.

Ibu Lidya: saya mengajarkan anak saya dengan memberikan contoh langsung untuk mengerjakan suatu hal yang baik.

Bapak Aris: "saya memberikan contoh dengan mengajaknya langsung untuk melakukan hal kebaikan, seperti sholat".

Bapak Rahmat: memberikan pengarahan terlebih dahulu, barulah diajak secara langsung dalam melakukannya, seperti menghormati orang yang lebih tua.

Dalam hal ini Orangtua merupakan orang terdekat dari kehidupan para remaja, sehingga orangtua sangat berperan di dalam kehidupan mereka. Orangtua mengajarkan kepada mereka nilai-nilai kehidupan yang baik kepada mereka, agar mereka mampu memahami kehidupannya dan agar mereka mampu menerapkan nilai-nilai tersebut di dalam kehidupannya kedepan. Orangtua mengharapkan anak-anak mereka menjadi orang-orang yang berakhlakul karrimah dan yang mampu menempatkan posisi mereka pada kehidupan kedepannya.

Orang tua memiliki peran yang sangat penting dalam membina akhlak remaja, oleh karena itu orangtua harus benar-benar semaksimal mungkin mendidik anak-anak mereka, agar mereka memiliki akhlakul karrimah yang diharapkan para orangtua. 
b. Memberi contoh yang baik terhadap remaja.

Memberi contoh yang baik bagi remaja dalam berpegang teguh kepada akhlak mulia. Di sini orangtua mengajarkan kepada anaknya untuk sopan dan santun terhadap orang yang lebih tua darinya, keyakinan yang didasarkan atas pengertian yang sungguh-sungguh tersebutlah yang mampu membuat remaja tumbuh menjadi remaja yang baik budi pekertinya.

Orangtua juga harus mampu memberikan contoh yang baik kepada anak-anak mereka, karena apabila orangtua tidak memberikan contoh yang baik maka para remaja mengira orangtuanya membebaskannya untuk berprilaku semena-mena terhadap orang lain. Orangtua harus mencontohkan kepada remaja bagaimana hal-hal yang baik yang harus ia lakukan dalam kehidupan, seperti menyampaikan amanah, sopan santun dan terutama dalam berakhlakul karrimah kepada orangtua dan orang lain.

Peran orangtua tidak hanya mengajarkan anak untuk mandiri, akan tetapi orangtua juga memberikan contoh yang baik kepada anak-anaknya agar mereka mau melakukannya.

Hasil observasi yang Peneliti lakukan terkait dengan pendidikan akhlak remaja dalam keluarga dapat dinilai baik, hal ini dapat dilihat bahwa orangtua sudah memberikan contoh kepada anak-anaknya sebagai cara untuk membina akhlakul karrimah kepada remaja, salah satunya adalah dengan mengajarkan secara langsung apa yang orangtua perintah.

Selanjutnya hasil wawancara dengan para orangtua remaja di Desa Mekarwangi RT.04/02 Cisauk Tangerang. Seperti yang dikatakan oleh Ibu Limah: iya, saya selalu memberikan contoh kepada anak saya untuk menghormati orang lain."

Ibu Ira juga menyatakan: saya itu orang yang cerewet dengan kehidupan, sehingga saya selalu cerewet untuk mengajarkan anak saya untuk berakhlak mulia, saya memberikan contoh kepada anak saya dengan cara mengarahkan dan mencontohkan langsung.

Ibu Eras: "saya biasanya memberikan contoh untuk berbuat baik kepada orang lain, pertama-tama saya ajarkan untuk berbuat baik kepada saudara sendiri."

Bapak Aris pun berkata bahwa: "saya selalu mendidik anak saya sejak kecil hingga remaja dengan cara memberikan contoh yang baik, agar dia mampu memahami mana yang baik dilakukan, memberikan contoh untuk menghormati orang yang lebih tua dari dirinya, selalu menyampaikan amanah ketika ia diberikan amanah oleh orangtua maupun orang lain, serta selalu mengajaknya untuk bersilaturahmi kepada kakungnya."

Bapak Rahmat juga menyatakan bahwa: saya mengajarkan dengan menasehati dan mengajak anak saya secara langsung.

Hasil observasi yang Peneliti lakukan terkait dengan pendidikan akhlak remaja dalam keluarga dapat dinilai kurang, hal ini dapat dilihat dari tanggapan para remaja yang masih suka tidak mendengarkan apa yang di perintahkan oleh orangtuanya.Selanjutnya hasil wawancara dengan para orangtua remaja di desa tersebut, dapat dilihat di bawah ini yang pertama.

Ibu Limah: ya terkadang mendengarkannya saja, kadang-kadang juga setelah diberikan contoh dia langsung mengerjakannya.

Ibu Ira: ketika saya mengarahkannya dia terdiam sebentar, baru melakukan yang saya katakan. Kadang juga mendengarkan tetapi tidak dilakukan hanya ia-ia saja.

Bapak Aris: ketika saya mengarahkan dia terdiam setelah saya selesai mengarahkan dia bertanya terlebih dahulu tentang apa yang saya katakan.

Bapak Rahmat: responnya terdiam terlebih dahulu ketika saya mengarahkannya, lalu baru ia lakukan apa yang sudah saya katakan.

Berdasarkan hasil wawancara yang Peneliti lakukan terkait dengan pendidikan akhlak remaja dalam keluarga dapat dinilai kurang, walaupun 
orangtua sudah semaksimal mungkin memberikan pengajaran kepada remaja untuk selalu tepat amanah, tetapi masih sangat jarang remaja mau menyampaikan amanah tersebut.

Sedangkan hasil wawancara dengan para orangtua tentang mengajarkan remaja untuk selalu amanah itu adalah suatu tanggungjawab yang sangat sulit bagi semua manusia. Ketika mendapatkan amanah maka pada saat itu juga amanah tersebut harus disampaikan. Seperti pernyataan Ibu Lidya: "tentu, karena amanah itu wajib disampaikan jadi saya harus mengajarkan kepada anak saya, bahwa jika dia mendapatkan amanah maka dia harus menyampaikannya".

Ibu Erna: "iya, saya mengajarkan untuk selalu menyampaikan amanah kepada orang yang akan mendapatkan amanah tersebut. Tetapi kadang-kadang dia mau jadi anak yang amanah, jika lagi kumat malesnya dia tidak amanah".

Ibu Eris: "saya mengajarkannya kepada anak saya, karena amanah itu adalah tanggungan yang harus disampaikan. Jika tidak disampaikan maka dia berdosa. Setelah berkata seperti itu anak saya langsung bilang ia".

Bapak Aris: "mengajarkan anak tentang akhlakul karrimah adalah wajib bagi orangtua, jadi mengajarkan amanah tentu harus dilakukan, agar anak tahu bahwa suatu amanah itu adalah tanggungan yang wajib disampaikan.

Bapak Rahmat: "iya tentu mengajarkan, amanah adalah termasuk akhlakul karrimah, sehingga orangtua harus mengajarkannya. Walaupun mereka masih sering tidak menjalankan amanah tersebut tetapi kita sebagai orangtua tetap harus berusaha.

Jadi bahwasanya dari poin ke dua ini orangtua lebih sering memberikan contoh yang baik kepada anaknya agar anaknya menjadi anak yang baik akhlakul karrimahnya. Orangtua mengajarkan tentang berbagai macam, sehingga anak dapat memahami apa yang harus dilakukan dan yang tidak boleh dilakukan.
Peran orangtua dalam mendidik akhlak remaja sangatlah penting karna akhlak sangat diperlukan dalam kehidupan sebagai tatakrama bermasyarakat, dan selalu harmonis dengan para masyarakat yang lain.

c. Memberi tanggung jawab dalam kehidupan remaja.

Orangtua memberikan kebebasan dalam kehidupan anaknya, akan tetapi orangtua juga wajib menjalankan tanggungjawabnya dalam memberikan arahan untuk berbuat baik di dalam hidupnya. Hal ini seperti orangtua memberikan kebebasan kepada anaknya agar mereka mampu mengenali semua hal-hal yang ada, tetapi orangtua tetap harus mengawasi dan memantau semua yang dilakukan remaja.

Kebebasan yang orangtua berikan harus dimanfaatkan para remaja untuk mengetahui berbagai hal yang positif yang dapat memberikan pengetahuan tentang kehidupan. Jadi, orangtua tetap harus memantau apa yang dilakukan oleh remaja, orangtua bertanggungjawab untuk mendidiknya dalam akhlakul karrimahnya agar ia di dalam kehidupan nyata memiliki akhlakul karrimah yang baik.

Berdasarkan Hasil observasi yang Peneliti lakukan terkait dengan pendidikan akhlak remaja dalam keluarga dapat dinilai baik, karena dapat dilihat dari tanggungjawab orangtua dalam membimbing akhlakul karrimah remaja, dengan adanya bimbingan tersebut maka orangtua sudah melaksanakannya dengan baik, hanya saja perlu lebih maksimal lagi.

Selanjutnya hasil wawancara yang peneliti lakukan dapat diuraikan sesuai dengan poin ke-3 tentang tanggungjawab orang tua.

Ibu Eras: "saya sebagai orangtua tentu harus bertanggung jawab dalam mendidik anak saya terutama dalam sopan santun, karena sopan santun adalah tatanan nilai yang harus ia miliki sebagai bekal ketika dia memasuki masa-masa bersosialisasi di masyarakat."

Ibu Limah: "saya sebagai orangtua wajib memberi tanggung jawab kepada anak saya, terutama dalam hidupnya. 
Saya memberikan kebebasan dalam bergaul kepada anak saya, tetapi saya juga harus tetap mengawasinya karena belum tentu teman-teman yang bermain dengannya memiliki akhlak yang baik, sehingga saya harus tetap mengarahkan anak saya untuk selalu bersikap baik."

Ibu Ira: "sudah, saya sebagai ibu bertanggung jawab untuk merawat, dan mengajarkan tentang akhlakul karrimah"

Bapak Aris: "saya sebagai seorang bapak wajib tanggung jawab terhadap anak saya."

Bapak Rahmat: "orangtua wajib memberikan tanggungjawab kepada anaknya, tidak hanya menafkahi tetapi juga mengarahkan agar jadi anak yang punya sopan santun.

Berdasarkan Hasil observasi yang Peneliti lakukan terkait dengan pendidikan akhlak remaja dalam kelaurga dapat dinilai baik, hal ini dapat dilihat dari tanggungjawab yang sudah orangtua lakukan untuk para remaja, seperti bimbingan dalam ilmu pengetahuan maupun bimbingan dalam ke agamaan.

Hasil wawancara tentang tanggungjawab orangtua yang peneliti dapatkan yang pertama yaitu, Ibu Lidya: saya mengasuhnya saat dia bayi, mengajarkannya dari kecil tentang agama sampai saat ini.

Ibu Erna: saya sebagai orangtua merawatnya sejak bayi sampai saat ini dia sudah remaja, saya memberikan pengarahan dalam hidupnya agar dia bisa bersraung terhadap orang lain.

Ibu Limah: menasehati, mengarahkan untuk berbuat baik terhadap orang lain, dan menghormati orang lain.

Bapak Aris: tanggung jawab yang sudah saya berikan itu ialah mengajarkan anak saya untuk berakhlakul karrimah, itu hal yang pertama yang harus saya ajarkan kepada anak saya, karena ketika dia berakhlakul karrimah tentu nantinya dia akan mudah bersosialisasi dengan lingkungan sekitar, kemudian saya mengajak anak saya untuk selalu menunaikan ibadah yang sudah menjadi kewajibannya, dan saya selalu menasehatinya untuk selalu mengingat siapa dia dan siapa yang menciptakan dirinya, dan apa tugasnya di muka bumi ini.

Bapak Rahmat: "tanggung jawab yang saya berikan kepada anak saya adalah memberikan kesempatan kebebasan dalam bersosialisasi akan tetapi saya harus tetap mengawasi dan selalu memberikan nasehat kepada anak saya."

Jadi, peran orangtua dalam membina akhlak remaja, itu sangat penting bagi anak-anaknya, dan tanggung jawab tentunya suatu kewajiban yang harus orangtua berikan, kewajibannya orangtua sangatlah banyak, seperti mengarahkan anak-anaknya untuk tetap berada di dalam jalan yang benar, yang mengetahui apa kewajiban manusia hidup di bumi ini. Orangtua juga mengajarkan bagaimana hidup rukun bersama masyarakat sekitar, dengan cara saling menghormati, serta selalu tepat amanah ketika diberikan amanah oleh orang lain. Orangtua juga mengajarkan kepada anak-anaknya untuk selalu bertutur kata yang baik terhadap orang yang sudah tua atau dengan teman yang lebih tua darinya.

d. Membiasakan remaja untuk berakhlak mulia, beribadah, dan disiplin.

Orang tua mengajarkan remaja untuk bersikap baik terhadap orang lain, dengan cara membiasakannya untuk makan bersama keluarga, sehingga mereka tahu akhlak sopan santun menghargai orang lain, membiasakan untuk melakukan ibadahibadah lain, seperti sholat, puasa, dan lainnya, serta membiasakan kedisiplinan sebagai penyeimbang terhadap kebebasan yang diberikan kepada anak agar ia terlatih dan dapat terkontrol dengan menerapkan bentuk tingkah laku sesuai ajaran Islam.

Orang tua merupakan pendidik yang pertama memberikan ilmu pengetahuan, orangtua pula yang menjadi seorang penasehat bagi anaknya, mengajarkan anak dari kecil hingga dewasa, orangtua juga sebagai teman bagi seorang anak, saling tukar fikiran dan orangtua pun dapat sebagai teman yang bisa 
membantu memecahkan permasalahan yang sedang dihadapinya.

Orangtua mengajarkan kepada anaknya sopan santun agar anaknya mampu memiliki akhlak yang mulia, seperti bertutur kata yang baik terhadap orangtua dan orang lain, menghormati, saling tolong menolong, selalu tepat amanah ketika mendapat amanah, orangtua juga mengajarkan kepada anaknya untuk disiplin dalam beribadah, selalu tepat waktu dalam melaksanakan sholat lima waktu, selalu melaksanakan sholat berjamaah, serta orangtua mengajarkan untuk disiplin berbagai hal, sehingga anak akan terbiasa dengan hal-hal yang sudah diajarkan oleh orangtuanya.

Berdasarkan hasil observasi yang Peneliti lakukan terkait dengan pendidikan akhlak remaja dalam keluarga dapat dinilai baik, hal ini dapat dilihat dari cara orang tua membiasakan remaja untuk baik terhadap orang lain. Hasil wawancaranya dengan Orangtua juga menerangkan bahwasanya orangtua biasanya mengajarkan kepada para remaja untuk berakhlak mulia kepada semua orang, seperti yang dikatakan oleh, Ibu Lidya: "saya selalu mengarahkan anak saya untuk berakhlak mulia, karena akhlak mulia itu diperlukan dalam kehidupan."

Ibu Erna: "Saya seorang ibu tentu mengajarkan anak saya untuk berakhlak mulia, karena itu perlu dalam kehidupan sehari-hari."

Ibu Limah: "orangtua harus mengawali terlebih dahulu suatu kegiatan agar anak mau mengerjakan hal yang kita perintahkan, dengan seperti itu anak pasti mau melakukannya."

Bapak Aris: "saya sebagai bapak juga harus mengajarkan anak saya untuk berakhlak mulia."

Bapak Rahmat: "semua orangtua pasti selalu mengajarkan kepada anaknya untuk membiasakan agar berakhlak mulia, saya juga sebagai orangtua pasti mengarahkan anak untuk selalu berakhlak mulia kepada semua orang."

Berdasarkan Hasil observasi yang Peneliti lakukan terkait dengan pendidikan akhlak remaja dalam keluarga dapat dinilai baik, hal ini dapat dilihat dari cara orangtua membiasakan remaja untuk melakukan ibadah sholat berjamaah di rumah maupun di masjid. Orangtua membiasakan remaja untuk melakukan hal itu agar mereka nantinya dapat terbiasa saat mereka sudah tumbuh dewasa dan jauh dari orangtuanya.

Selanjutnya hasil wawancara dengan para Orangtua remaja di desa Mekarwangi. Seperti kata: Ibu Eras: saya juga mengajarkan anak saya untuk selalu sholat berjamaah di masjid bersama ayah dan kakaknya, dan saya mengajarkan kepada anak saya dengan cara membiasakan disiplin dalam melaksanakan sholat lima waktu.

Ibu Ira: saya juga membiasakan anak saya untuk selalu melaksanakan ibadah sholat lima waktu berjamaah di masjid.

Ibu Lidya: saya mengarahkan anak saya untuk membiasakan sholat berjamaah dengan masyarakat di masjid.

Bapak Aris: saya juga membiasakan anak saya untuk sholat berjamaah di masjid bersama saya, dan membiasakan disiplin dalam mengerjakan ibadah sholat.

Berdasarkan Hasil observasi yang Peneliti lakukan terkait dengan pendidikan akhlak remaja dalam keluarga dapat dinilai baik, hal ini dapat dilihat dari cara orangtua membiasakan remaja untuk melakukan hal-hal kecil secara tepat waktu, agar dia bisa menjadi anak yang bisa disiplin dalam kehidupan dunia maupun kegiatan yang lebih keagamaan.

Selanjutnya hasil wawancara dengan para orangtua yang juga mengajarkan kepada remaja untuk menjadi orang yang selalu di siplin. Senada dengan pernyataan para orangtua berikut: Ibu Eras: dengan membiasakan anak disiplin, seperti saya membiasakan untuk disiplin sholat pada waktunya.

Ibu Ira: saya membiasakan dia untuk melakukan hal-hal yang lain dengan baik, misalnya setelah makan saya biasakan dia untuk mencuci piringnya sendiri, agar dia mandiri dengan dirinya. 
Ibu Lidya: saya membiasakan untuk selalu merapihkan tempat tidur, sebagai tanda tolong menolong terhadap orangtua.

Bapak Aris: biasanya saya membiasakan untuk bangun awal agar dapat melaksanakan sholat subuh tepat waktu di masjid.

Bapak Rahmat: saya mendisiplinkan anak dengan mendisiplinkan tepat waktunya dalam segala hal, mulai dari sholat, dan lainnya.

Jadi, peran orangtua dalam mendidik akhlak remaja sangat penting, orangtua membina akhlak remaja dimulai dari cara membiasakan kegiatan anaknya, orangtua mengajarkan dengan cara membiasakan agar anak terbiasa dengan apa yang dilakukan. Orangtua mendidik dan mengarahkan anaknya untuk berakhlak mulia merupakan kewajiban orangtua yang harus dilaksanakan, agar nantinya anak dapat menjadi masyarakat yang berakhlak mulia.

Pendidikan akhlak remaja dalam keluarga itu sangatlah penting bagi perilakunya, karena orangtua merupakan contoh pertama yang akan dicontoh oleh anak mereka. Para remaja akan menganggap apa yang orangtua lakukakn merupakan suatu contoh yang harus mereka tirukan. Jadi, orangtua harus memberikan pemahaman terlebih dahulu kepada remaja tersebut.

\section{PEMBAHASAN}

1. Pendidikan Akhlak Remaja dalam Keluarga di Kampung Kandang Desa Mekarwangi RT. 04 RW.02Cisauk Tangerang

Orangtua merupakan orang pertama yang sangat besar perannya dalam mendidik, membina pendidikan anak, maka dari situlah masa depan anak bisa dilihat apakah berkembang dengan baik, dalam bimbingan kedua orangtuanya selama ini. Peran orangtua harus diperhatikan dengan baik sehingga pribadi anak dapat bertumbuh dengan sempurna. Oleh karena itu, orangtua harus memelihara anaknya dengan baik agar menjadi penerus generasi mendatang yang memiliki akhlaqul karimah yang baik dan dijunjung tinggi oleh semua umat, anak merupakan tanaman kehidupan, yang dimana tanaman ini akan baik apabila ia dirawat dengan baik, dan sebaliknya tanaman ini akan rusak apabila tidak diperhatikan dan dirawat.

Berdasarkan deskripsi data dan penyajian data yang telah Peneliti uraikan di atas berdasarkan realita yang ada, maka dalam bagian ini Peneliti akan menyajikan analisis data yang diperoleh dari hasil penelitian di lapangan yang disesuaikan dengan tujuan pembahasan skripsi berikut:

\section{a. Memberi pengajaran akhlakul karrimah kepada remaja.}

Anak yang memasuki remaja pertengahan merupakan remaja yang mulai aktif dalam setiap hal, dan bertambahnya rasa keingintahuannya terhadap berbagai hal, sehingga di sinilah orangtua harus memberikan pengajaran tentang akhlakul karrimah. Orangtua harus memberikan pengajaran kepada anaknya tentang sopan santun atau berbuat baik, berprilaku baik terhadap orang lain, selalu mendengarkan nasehat yang diberikan kepadanya, dan lain sebagainya. Orangtua juga harus mengajarkan tentang sopan santun secara terus menerus kepada anaknya. Memberikan pengajaran tentang akhlakul karrimah, itu merupakan kwajiban orangtua, karena orangtua harus mengajarkan anak-anaknya tentang sopan santun, agar ketika anak dewasa ia akan terbiasa.

Berdasarkan penyajian data di atas, dari berbagai hasil wawancara dengan berbagai sumber bahwa, peran orangtua dalam membina akhlak remaja harus diawali dengan pengajaran sejak dini kepada para remaja. Jadi, orangtua di desa Mekarwangi ini telah terlaksanakan dengan baik, dapat dilihat dari peran Orangtua sebagai pembimbing utama yang harus memberikan pengajaran tentang akhlakul karrimah, sehingga dengan begitu para remaja akan terbiasa berakhlak baik. Peran orangtua akan berhasil jika anaknya bisa 
mengamalkan apa yang orangtua ajarkan dalam kehidupannya.

b. Memberi contoh yang baik terhadap remaja

Orangtua merupakan seseorang yang dijadikan panutan bagi para remaja sejak kecil sampai saat ini, jadi orangtua harus memberikan contoh yang baik kepada anak-anaknya. Orangtua harus selalu memberikan contoh yang baik kepada anaknya, untuk berakhlak mulia, dengan memberikan contoh langsung kepada anak, anak akan tahu bahwa orangtua mengajarkan hal baik kepadanya. Mula-mula orangtua mengajarkan untuk berbuat baik kepada saudara sendiri.

Berdasarkan penyajian data, dari berbagai hasil wawancara dengan berbagai sumber di atas bahwasanya Peneliti dapat mengambil kesimpulan bahwa, peran orangtua ini telah dilakukan tetapi dalam tanggapan para remaja masih kurang terlaksana dengan baik, hal ini masih dapat dilihat dari adanya ketidak patuhanya anak kepada orangtua. Walaupun orangtua sudah maksimal dalam memberikan contoh yang baik kepada remaja, tetapi masih banyak yang tidak segan untuk melakukan apa yang orangtua perintah.

c. Memberi tanggung jawab dalam kehidupan remaja

Orangtua memberikan kebebasan dalam kehidupan anaknya, akan tetapi orangtua juga wajib menjalankan tanggungjawabnya dalam memberikan arahan untuk berbuat baik di dalam hidupnya.

Orangtua tentu harus bertanggung jawab dalam mendidik seorang anak terutama dalam sopan santun, karena sopan santun adalah tatanan nilai yang harus di miliki. Memberikan kebebasan dalam bergaul kepada seorang anak itu perlu, akan tetapi orangtua juga harus tetap mengawasinya, orangtua juga harus tetap mengarahkan anak untuk selalu bersikap baik.

Berdasarkan penyajian data, dari berbagai hasil wawancara dengan berbagai sumber di atas bahwasanya Peneliti dapat mengambil kesimpulan bahwa, peran orangtua ini telah dilakukan dengan baik, hal ini dilakukan orangtua dengan berusaha semaksimal mungkin dalam membina akhlak remaja, tidak hanya dengan cara mengajarkannya saja tetapi juga dengan disertai contoh-contoh yang baik, karna itu merupakan tanggungjawab bagi setiap orangtua untuk mendidik anaknya menjadi remaja yang baik.

d. Membiasakan remaja untuk berakhlak mulia, beribadah, dan disiplin

Keluarga sebagai orangtua tentu wajib memberikan bimbingan kepada anaknya untuk melakukan hal-hal positif dan yang bermanfaat bagi anaknya. Orangtua mengajarkan remaja untuk lebih mudah mengerjakannya dengan cara pembiasaan.

Orangtua membiasaan anaknya untuk berakhlak mulia, kemudian dalam beribadah. Sehingga anak akan lebih mudah untuk melaksanakan halhal tersebut karena sudah terbiasa. Orangtua mengarahkan seorang anak untuk berakhlak mulia, orangtua juga harus mengawali terlebih dahulu suatu kegiatan agar anak mau mengerjakan hal yang orangtua perintahkan, membiasakan anak untuk melakukan sholat berjamaah di masjid, dan membiasakan disiplin dalam mengerjakan ibadah lainnya, serta mengajarkan kepada remaja untuk disiplin dalam semua kegiatan yang remaja lakukan.

Berdasarkan penyajian data di atas, dari berbagai hasil wawancara dengan berbagai sumber bahwa, peran orangtua dalam membina akhlak remaja telah dilakukan dengan baik, hal ini dilakukan orangtua dengan cara membiasakan anaknya untuk berakhlak mulia, dan membiasakan untuk mengerjakan ibadah khususnya sholat berjamaah di masjid, dan disiplin dalam kegiatan yang lain.

\section{SIMPULAN}

Berdasarkan uraian-uraian sebelumnya di atas, maka Peneliti dapat menarik kesimpulan bahwa: 
1. Pendidikan Akhlak Remaja dalam Keluarga di Desa Mekarwangi RT.04/02 Cisauk Tangerang

a. Peran orangtua di desa Mekarwangi RT.04/02 Cisauk Tangerang yaitu, Memberi pengajaran akhlakul karrimah kepada remaja, telah diterapkan oleh semua orangtua kepada remaja, sehingga mereka memiliki sopan santun, walaupun tidak semua remaja di desa tersebut memiliki akhlak yang baik. Akan tetapi orangtua di desa tersebut sudah semaksimal mungkin berperan dalam membina akhlak remaja. Jadi, orangtua di desa Mekarwangi ini telah melaksanakn perannya dengan baik dalam mendidik akhlak anak remajanya, hal ini dapat dilihat dari peran orangtua sebagai pembimbing utama yang harus memberikan pengajaran tentang akhlakul karrimah, sehingga dengan begitu para remaja akan terbiasa berakhlak baik. Peran orangtua akan berhasil jika anaknya bisa mengamalkan apa yang orangtua ajarkan dalam kehidupannya.

b. Orang tua di Desa Mekarwangi RT.04/02, sudah melaksanakan tugas orangtua dalam membina akhlak remaja dengan cara Memberikan contoh yang baik terhadap remaja. Sehingga remaja dapat mengikuti apa yang harus dilakukan oleh remaja. Akan tetapi remaja di desa tersebut masih ada yang tidak mau melakukan hal-hal yang sudah dicontohkan oleh orangtua, jadi orangtua masih harus memaksimalkan bimbingannya kepada remaja.

c. Orang tua juga harus melakukan kewajibannya seperti memberi tanggung jawab terhadap remaja, tanggungjawab terhadap pendidikan akhlakul karimah, dan tanggung jawab dalam hal apapun.

d. Orang tua juga harus membiasakan remaja untuk berakhlak mulia, beribadah, dan disiplin. Karena itu termasuk kewajiban setiap orangtua untuk membina akhlak remaja, yang dimulai dari cara pembiasaan dalam kegiatan apapun, dengan begitu remaja akan terbiasa melakukan ibadah berjamaah, dan semua kegiatan positifnya.

\section{DAFTAR PUSTAKA}

Departemen Agama Islam RI. 2005. AlQur'an dan Terjemahnya. Jakarta

Jamaluddin, Dindin. 2013. Paradigma Pendidikan Anak dalam Islam, Pustaka Setia. Bandung.

Mahmud, Ali Abdullah Halim. 2004. Akhlak Mulia. Gema Ismani. Jakarta

Ni'am, Munawa. 1992. Undang-undang Sistem Pendidikan Nasional. Media Wacana Press. Yogyakarta.

Sarwono, Sarlito W. 2016. Pengantar Psikologi Umum, Rajagrafindo Persada, Jakarta.

Sugiyono. 2017. Metode Penelitian Pendidikan. Alfabeta. Bandung.

Syah, Muhibbin. 2013. Psikologi Pendidikan dengan Pendekatan Baru, Cet 18. PT. Remaja Rosdakarya. Bandung

Zahrudin dan Sinaga, Hasanuddin. 2004., Pengantar Studi Akhlak. Raja Grafindo Persada, Jakarta. 